\title{
How (specific) would you like your T-cells today? Generating T-cell therapeutic function through TCR-gene transfer
}

\author{
Inbal Daniel-Meshulam ${ }^{\dagger}$, Shlomo Ya'akobi ${ }^{\dagger}$, Chen Ankri and Cyrille J. Cohen* \\ Laboratory of Tumor Immunology and Immunotherapy, The Mina and Everard Goodman Faculty of Life Sciences, Bar-Ilan University, Ramat Gan, Israel
}

\author{
Edited by: \\ Vincenzo Bronte, Immunology Unit, \\ Italy \\ Reviewed by: \\ Luca Gattinoni, National Cancer \\ Institute, USA \\ Vincenzo Russo, San Raffaele \\ Scientific Institute, Italy \\ *Correspondence: \\ Cyrille J. Cohen, Laboratory of Tumor \\ Immunology and Immunotherapy, The \\ Mina and Everard Goodman Faculty \\ of Life Sciences, Bar-llan University, \\ Gonda Building 204, Room 105, \\ Ramat Gan 52900, Israel. \\ e-mail: cohency@mail.biu.ac.il \\ †Inbal Daniel-Meshulam and Shlomo \\ Ya'akobi have contributed equally to \\ this work.
}

\begin{abstract}
T-cells are central players in the immune response against both pathogens and cancer. Their specificity is solely dictated by the T-cell receptor (TCR) they clonally express. As such, the genetic modification of T lymphocytes using pathogen- or cancer-specific TCRs represents an appealing strategy to generate a desired immune response from peripheral blood lymphocytes. Moreover, notable objective clinical responses were observed in terminally ill cancer patients treated with TCR-gene modified cells in several clinical trials conducted recently. Nevertheless, several key aspects of this approach are the object of intensive research aimed at improving the reliability and efficacy of this strategy. Herein, we will survey recent studies in the field of TCR-gene transfer dealing with the improvement of this approach and its application for the treatment of malignant, autoimmune, and infectious diseases.
\end{abstract}

Keywords: T-cell receptor, TCR-gene transfer, T-cells, immunotherapy, cancer, infectious diseases, autoimmunity

\section{INTRODUCTION - TCR-GENE TRANSFER FROM BENCH TO BEDSIDE}

As an integral part of the adaptive immune system, T-cells have been attributed several protective functions directed against both microbial pathogens and tumor cells. Although derived from the self, neoplastic cells often express tumor antigens that can discriminate them from normal tissues and can be recognized by the adaptive immune system (Novellino et al., 2005). Indeed, T lymphocytes demonstrate the capacity to eradicate cancer cells and a growing body of studies has shown that the adoptive cell transfer (ACT) of tumor-specific T lymphocytes (Hawkins et al., 2010; Restifo et al., 2012) isolated from the tumor itself has been demonstrated to mediate impressive tumor regression in advanced melanoma patient, with almost a quarter of the treated individuals durable complete responders (Rosenberg et al., 2011). Clinical trials based on adoptive T-cell transfer have been conducted in the last two decades for the treatment of viral conditions (Fujita et al., 2008; Berger et al., 2009), especially in the context of bone marrow transplantation. Initially targeting cytomegalovirus (CMV; Walter et al., 1995), this strategy has been extended to other viruses such as Epstein-Barr virus (EBV; Heslop et al., 1996), adenoviruses (Feuchtinger et al., 2006), and multiple viruses simultaneously (Leen et al., 2006).

Still, the isolation of such antigen-specific T-cells is not always possible and as such, alternative approaches have been designed to enable the generation of antigen-specific lymphocytes from peripheral T-cells. T lymphocytes can recognize their cognate

Abbreviations: CTL, cytotoxic T-cells; HLA, human leukocyte antigen; MHC, major histocompatibility complex; OR, objective response; TCR, T-cell receptor. antigen through the binding of their T-cell receptor (TCR) to an epitope presented by major histocompatibility complex (MHC) molecules on the target cells (Vyas et al., 2008). This implies that the TCR dictates the specificity of a given T-cell and that it should prove feasible to provide T-cells with new specificities by transferring the genes of a given TCR. The successful reprogramming of T-cell specificity by TCR-gene transfer was first demonstrated by Steinmetz and colleagues in a murine system (Dembic et al., 1986). Originally, the purpose of this report was to study the receptor dynamics, but it opened a novel field of therapeutic research dealing with gene-mediated redirection of T-cell specificity. This approach was then applied to endow T-cells with tumor specificity using a melanoma-specific TCR in vitro (Clay et al., 1999), and subsequently in vivo, using an influenza virus-specific receptor (Kessels et al., 2001).

Basically, this strategy relies on the isolation of the genes encoding the $\alpha$ and $\beta$ chains of a TCR specific for an antigen from a T-cell clone (e.g., from tumor-infiltrating lymphocytes (TILs), peptide-stimulated PBLs from healthy individuals or from immunized human leukocyte antigen (HLA)-transgenic mouse). While the rapid isolation of suitable TCRs for therapy remains a challenge due in part to their high variability (around 40-50 different framework genes for either the $\alpha$ or the $\beta$ ), multiple strategies (mainly using sets of primers for TCR- $5^{\prime}$ regions or the rapid-amplification of cDNA ends - RACE) have been published (Aarnoudse et al., 2002; Boria et al., 2008; Birkholz et al., 2009; Walchli et al., 2011). Then, these $\alpha$ and $\beta$ chains are cloned into an expression vector and transduced to previously stimulated normal peripheral $\mathrm{T}$ lymphocytes. This enables the reprogramming of the adaptive immune response against antigens of choice based on the 
specificity of the introduced TCR (reviewed elsewhere; Schmitt et al., 2009; Udyavar and Geiger, 2010; Thomas et al., 2010). Several clinical studies were elaborated based on this conceptual approach for the treatment of advanced cancer patients: Morgan et al. (2006) demonstrated for the first time that it was possible to transduce normal autologous PBLs from stage IV-metastatic melanoma patients with an MART1-specific TCR and generate large numbers of MART1-specific cells $\left(10^{9}-10^{10}\right)$ to be infused back to the patients. In this Phase I clinical trial, 17 metastatic melanoma patients were treated and 2 of them (12\%) demonstrated dramatic tumor regression leading to an objective clinical response. This was followed by a second study in which the same group made use of two high-affinity TCRs against the melanoma antigens MART-1 and gp100 (Johnson et al., 2006) (including an HLA-A2/gp100 154 -specific murine TCR) in a clinical trial (Johnson et al., 2009) in which the objective response (OR) rate raised to $30 \%$ of the patients treated. Recently, more clinical studies were aimed at exploring the therapeutic potential of TCR-gene transfer to target other cancers than melanoma, using carcinoembryonic (CEA)- (Parkhurst et al., 2011a), p53- (Davis et al., 2010), and NY-ESO- (Robbins et al., 2011) specific TCRs. The CEA-TCR and p53-TCR were based on murine TCRs isolated in HLA-A2 transgenic hosts and in each study, one patient responded to the treatment. Still, the CEA-TCR clinical trial was limited to only three patients, due to severe inflammatory colitis. Such toxicity emphasizes the possible on-target effects of such therapy. However, Robbins etal. (2011) reported encouraging results using an affinity-enhanced NY-ESO-1-specific TCR. Half (5/11) of the melanoma patients treated as well as $67 \%$ of the synovial cell cancer patients underwent an objective clinical response, with two complete responders. Notably, no toxicities were observed in all the patients treated.

Thus far, it has been reported that more than a hundred patients have been treated by the Rosenberg group in the Surgery Branch at NCI using TCR-gene transfer (Park et al., 2011). Nevertheless, several hurdles that may hinder the efficacy of these treatments have been identified along the years and several studies have attempted to solve these issues that include the type of the vector to be used, its configuration, the safety of the procedure, TCR chains mispairing, and the desired functional avidity of the reprogrammed cells. In the present review, we will aim at giving an overview of the recent development in this field and will also elaborate on the development of TCR-gene engineering for conditions other than neoplastic diseases.

\section{MANIPULATING THE FUNCTIONAL AVIDITY OF THE TCR-ENGINEERED CELLS}

One of the central questions that pertain to TCR-based gene modifications of lymphocytes is to what extent it is possible for the introduced TCR to reach similar levels of surface expression and functionality as the endogenous one. As T-cell functional avidity is dictated mainly by both TCR affinity and the number of TCR molecules expressed (Schodin etal., 1996), much efforts has been devoted to improving these biophysical properties in TCR-engineered cells using two important approaches: the improvement of TCR affinity and expression and the enhancement of TCR chain pairing and expression. Based on in vitro comparative assays (Johnson et al., 2006) and the recent solution of the crystal structure (Borbulevych et al., 2011) of a highly avid (DMF5) and a medium-avid (DMF4) MART1-specific TCRs, and on the other hand the results obtained in two clinical trials published using these TCRs (Morgan et al., 2006; Johnson et al., 2009), it is reasonable to surmise that the use of TCRs that endow T-cells with superior functional avidity might help to improve OR rates [i.e., 30\% OR for the DMF5 (Johnson et al., 2009) compared to $12 \%$ for the DMF4 (Morgan et al., 2006)]. In addition, TCR affinity increase can assist in augmenting T-cell sensitivity to tumors and in compensating for sub-optimal TCR expression. Such high-affinity TCR should also function in CD8-negative cells such as Th1 or Th17, providing additional support for the antitumor response (Cohen et al., 2005; Kuball et al., 2005; Udyavar et al., 2009). Several approaches to increase the functional avidity of TCR-engineered cells have been described lately (summarized in Figure 1).

\section{TCR AFFINITY MATURATION}

Because most of the tumor antigens are self antigens, the isolation of high-affinity TCR reactive against tumor antigen from human donors can represent a major challenge, since high-avidity CTLs specific for tumor cells may be deleted by negative selection. However, it is possible to increase TCR affinity by mutating selectively amino acids in polymorphic TCR complementarily determining regions - CDRs (Chlewicki et al., 2005). The screening of mutated TCRs using yeast or phage-display libraries can yield affinity improvement up to supra-physiological levels (Holler et al., 2000; Li et al., 2005). For example, Li et al. (2005) isolated NY-ESO-specific TCR with affinities in the picomolar range. Similarly, a Gag-specific TCR that underwent a 360-fold increase in affinity demonstrated a more efficient control of the spread of HIV virus in vitro (Varela-Rohena et al., 2008). Nevertheless, such affinity increase can prove detrimental to T-cell function by endowing T-cells with non-specific/self-reactivities (Zhao et al., 2007a) or, paradoxically, by causing defective recognition of low concentrations of antigen (Thomas et al., 2011). In parallel, some studies demonstrated the benefit of introducing a reduced number of CDR-targeted mutations; Robbins et al. (2008) increased the affinity of several TCR by several fold using an alanine-scan of CDR regions and site-directed mutagenesis of only one to two residues. This approach was used to increase the affinity of two TCRs, a CEA- and an NY-ESO1-specific TCRs, which were subsequently used in recent clinical trials (Parkhurst et al., 2011b; Robbins etal., 2011) in which several patients underwent clinical objective tumor regression. Another work recently showed that TCRs seldom express a glycine residue at position 107 in the CDR3 $\beta$ instead of serine. Based on modeling and molecular dynamics simulation, a G107S replacement led to 10-1,000fold increase in antigen sensitivity in three of four TCRs tested (Alli et al., 2011).

\section{ISOLATION OF TCRS FROM HLA-MISMATCHED- OR TRANSGENIC DONORS}

High-affinity TCRs could be isolated from HLA-mismatched donors (Sadovnikova and Stauss, 1996; Savage et al., 2004; Amir et al., 2011), HLA-transgenic mice (Theobald etal., 1995) or 


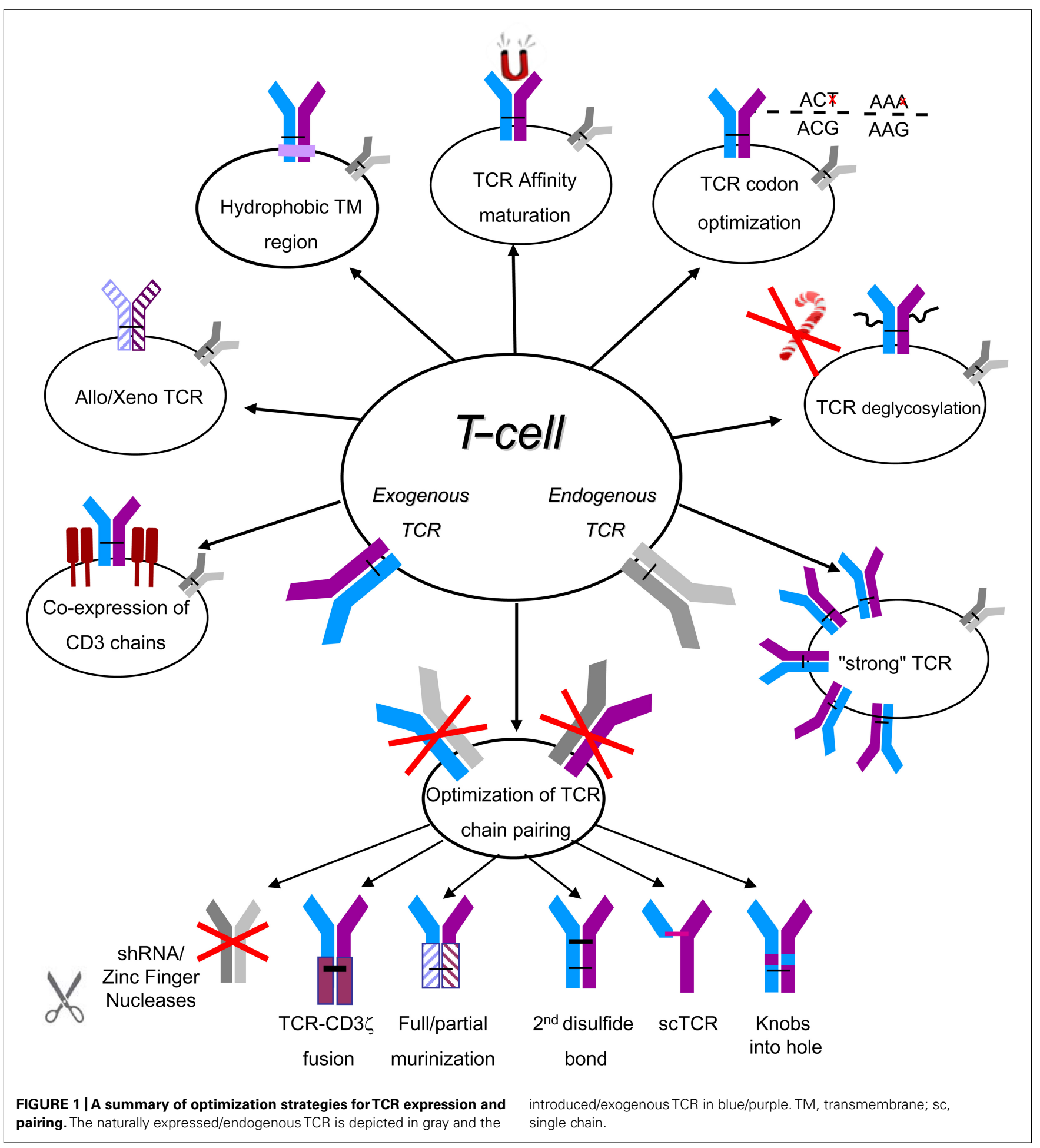

transgenic mice expressing the human TCR repertoire (Li et al., 2010), as logically, tolerance mechanisms should not influence non-self reactivity, provided the targeted $\mathrm{MHC} /$ peptide complex is recognized as foreign. Additionally, several models utilized HLA-A2 transgenic mice to isolate TCRs, which were revealed to display CD8-independent characteristics (Sherman et al., 1992). We and others showed that such murine TCRs can efficiently function in $\mathrm{CD}^{+}$cells (Cohen et al., 2005; Kuball et al., 2005; Johnson et al., 2009).

\section{TCR CODON OPTIMIZATION}

The genetic code bears some degrees of degeneration as a defined amino acid can be encoded by several (synonymous) codons, which are differentially represented in the cell. Moreover, cryptic 
splicing sites, mRNA secondary structure, and instability motifs can reduce the expression of proteins. Using algorithms to modify the DNA sequence of TCRs "silently," several TCRs have been "codon-optimized" leading to higher expression levels and enhanced reactivity both in vitro and in vivo (Scholten et al., 2006; Jorritsma et al., 2007).

\section{TCR DEGLYCOSYLATION}

Based on the fact that TCR glycosylation can reduce TCR expression and favor its internalization (Daniels et al., 2002), Kuball et al. (2009) demonstrated that the deletion of some of these $\mathrm{N}$-glycosylation sites (4-5 total in the constant domain) from either human or murine TCRs increased the functional avidity of T-cells transduced with these mutated TCRs.

\section{USE OF "STRONG" TCRs}

It appears that certain TCRs (termed "strong TCRs") can compete better for surface expression when expressed in the presence of various other TCRs (Sommermeyer et al., 2006; Heemskerk et al., 2007). TCR stability is likely to be influenced by protein dynamics and folding as well as interactions between the TCR-variable regions. However, it is unclear what determines the "strength" of a defined TCR a priori.

\section{INCORPORATION OF HYDROPHOBIC MUTATIONS IN THE TRANSMEMBRANE REGION}

The TCR transmembrane regions contain three positively charged residues that may be associated with the lack of stability of the entire chains (Soetandyo etal., 2010). We designed an original approach to selectively improve exogenous TCR stability by increasing the hydrophobic nature of the TCR $\alpha$ transmembrane region. Incorporation of hydrophobic residues at evolutionarypermissive positions resulted in an enhanced surface expression of the TCR chains, leading to an improved cellular avidity and anti-tumor TCR activity (Haga-Friedman et al., 2012).

\section{OPTIMIZATION OF TCR CHAINS PAIRING}

One of the central impediments in the TCR-gene transfer strategy lies with the mispairing of the exogenous $\alpha$ and $\beta$ TCR chains $\left(\alpha_{\mathrm{EX}}\right.$ and $\left.\beta_{\mathrm{EX}}\right)$ with the naturally expressed endogenous TCR chains ( $\alpha_{\text {NAT }}$ and $\beta_{\text {NAT }}$; reviewed in detail in Govers et al., 2010). Thus, four different $\alpha \beta$ dimers can form in the transduced cells: the endogenous TCR $\left(\alpha_{\text {NAT }} / \beta_{\text {NAT }}\right)$, the transduced (desired) TCR $\left(\alpha_{\mathrm{EX}} / \beta_{\mathrm{EX}}\right)$ as well as two mixed dimers $\left(\alpha_{\mathrm{EX}} / \beta_{\mathrm{NAT}}\right.$ and $\left.\alpha_{\mathrm{NAT}} / \beta_{\mathrm{EX}}\right)$. Since the surface expression of these TCR necessitates for these chains to assembly with a limited number of CD3 molecules, the existence of unproductive forms of TCR leads to reduced levels of the exogenous TCR. Additionally, two reports recently showed that these TCRs mixed heterodimers may engender autoimmunity manifestations and self-reactivity both in a mouse model (Bendle et al., 2010) and in vitro (van Loenen et al., 2010).

Consequently, many groups, including ours, are involved in developing approaches to reduce the mispairing effect as well as to promote the pairing of the exogenous TCR chains. These strategies include the addition of a second disulfide bond (Cohen et al., 2007; Kuball et al., 2007), the "murinization" of all or part of the TCR constant regions (Stanislawski et al., 2001; Cohen et al., 2006;
Voss et al., 2006; Thomas et al., 2007; Bialer et al., 2010; Sommermeyer and Uckert, 2010), the use of a "knob into holes" approach

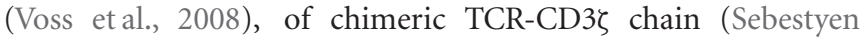
et al., 2008; Govers et al., 2011) or of single-chain TCRs (Chung etal., 1994; Voss etal., 2010; Aggen etal., 2012) and have been described in details in several reviews (Govers et al., 2010; Thomas et al., 2010; Merhavi-Shoham et al., 2012). In addition, shRNA sequences can be incorporated into the TCR encoding vector to knock down the expression of the endogenous TCR (Okamoto et al., 2009). Lately, another elegant approach to knock down the endogenous TCR was reported and is based on the use of zincfinger nucleases (ZFNs) that target the endogenous TCR $\alpha$ and $\beta$ chains (Provasi et al., 2012).

\section{CO-EXPRESSION OF CD3 CHAINS}

The restricted level of CD3 molecules can represent a bottleneck for TCR expression. Ahmadi et al. (2011) demonstrated that increasing the expression of CD3 chains (using polycistronic vectors) can boost the functional avidity of TCR-transduced T-cells and their in vivo performance.

\section{GENETIC APPROACHES AND TOOLS FOR THE ENGINEERING OF T-CELLS}

The genetic modification of T-cells with a TCR necessitates reliable platforms for the transfer of the genetic information. To date, most of the platforms used for TCR-gene transfer, both for research and in clinical settings, were based on $\gamma$-retroviral vectors such as the mouse stem cell virus (MSCV) or myeloproliferative sarcoma virus (MPSV; Morgan et al., 2006; Uckert and Schumacher, 2009). $\gamma$ retroviral vectors mediate genome integration of the transgene(s), which enables its long-term expression in the transduced cells. In this type of vectors, the exact cloning position of the transgene relative to cis-elements in the retroviral construct appears critical for proper expression of the TCR (Frankel et al., 2011). Also, retroviral vectors may demonstrate a risk of insertional mutagenesis, which can cause dysregulated gene expression and subsequent malignant transformation (Hacein-Bey-Abina et al., 2003). However, it is important to note that all the recent TCR-gene transfer clinical trials were based on the use of MSCV-based retroviral vectors (Park et al., 2011) and that no signs of lymphoproliferative disease were noted in the patients treated. Additionally, a comprehensive body of evidence support the notion that no replicative competent retroviruses (RCR) or adverse events have been observed in a considerable number of clinical trials (Bear et al., 2012). Still, primary lymphocyte stimulation is essential when using $\gamma$ retroviral vectors and the latter may shift the T-cell phenotype causing some levels of T-cells exhaustion (Gattinoni et al., 2005; Hinrichs et al., 2011). Interestingly, the TCR transgene expression in patients seems to decrease quite rapidly (1-2 weeks) following adoptive transfer unlike what was observed in in vitro conditions, where it can last several weeks (Burns et al., 2009). This decrease seems to be associated with lower general transcriptional activity of the transduced T-cells, in a similar way as for the endogenous TCR (van Loenen et al., 2011). However, this situation may be reversed when restimulating transduced cells.

It is also possible to utilize lentiviral platforms (Tsuji et al., 2005; Yang et al., 2008; Circosta et al., 2009; Jones et al., 2009) as they may 
provide the benefit of efficiently transducing non-dividing cells with a safer integration profile (Levine et al., 2006) and resistance to silencing (Frecha et al., 2010). Nonetheless, the use of stimulating factors such as cytokines is required to achieve desirable levels of TCR expression (Cavalieri et al., 2003; Jones et al., 2009; Perro et al., 2010). In mouse settings, a recent comparison of lenti- and retroviral vectors showed that the latter mediated better results in TCR-gene transfer assays (Kerkar et al., 2011).

Non-viral means to engineer T-cells would significantly reduce the need for intensive testing of the viral supernatant, reducing production time. As such, the use of in vitro-transcribed RNA molecules introduced by electroporation (Schaft et al., 2006a; Zhao et al., 2006a) or DNA constructs (Till et al., 2008) represents an interesting alternative for the gene modification of lymphocytes, not only for the rapid screening of gene function (Bialer et al., 2010; Almasbak et al., 2011) but also in potentially therapeutic settings (Zhao et al., 2010). On the other hand, the rapid disappearance of transgene after a few days (Zhao et al., 2006a) inherent to this transient system represents a major disadvantage of this approach. Another interesting non-viral approach is based on the use of the Sleeping Beauty transposon system (Ivics et al., 1997; Huang et al., 2006). In this system that was "resurrected" based on fossil sequences found in the genomes of salmonid fish, the gene(s) of interest are integrated into the genome using a transposase. This system necessitates the concomitant transfer of two nucleic acid polymers, one being the transposon encoding the gene(s) of interest and the other the transposase itself. In the context of TCR-gene transfer, the use of this approach has recently been reported to provide human T-cells with tumor specificity (Peng et al., 2009; Jin et al., 2011).

Beyond the type of vector to be used, it is important to note that as the TCR is a dimer formed of two chains, TCR $\alpha$ and TCR $\beta$, these have to be expressed simultaneously by the engineered cells. As the separate introduction of both chains in the recipient chains has proven difficult and rather ineffective, several vector designs strategies have been elaborated to facilitate the efficient expression of the TCR dimer (reviewed in Uckert and Schumacher, 2009). The two main strategies that have been utilized clinically rely on the use of either an internal ribosomal entry site (IRES) or a $2 \mathrm{~A}$ peptide sequence separating the two chains. One of the potential drawbacks related to the use of an IRES sequence is the possibility that the gene downstream of the IRES is expressed at a lesser level (Ghattas et al., 1991; Mizuguchi et al., 2000). Alternatively, a 2A peptide sequence, which is employed by several viruses such as the picornavirus (Szymczak and Vignali, 2005), provide an effective way to express simultaneously multiple proteins. Indeed, it has been showed that the 2 A peptide can promote a ribosomal "skip." We also showed that a furin cleavage site as well as an aminoacid spacer can be added to the $2 \mathrm{~A}$ sequence to enhance transgene expression (Yang et al., 2008). When comparing both approaches (IRES or 2A peptide) it has been showed that the latter may be better for efficient TCR expression (Leisegang et al., 2008).

Though most of the TCR-gene transfer studies are based on $\alpha \beta$ TCRs targeting an peptide/MHC class I complex, some reports have also made used of other types of receptors to target tumor cells both in vitro and in vivo: TCR specific for minor antigens (Heemskerk et al., 2003; Mommaas et al., 2005), MHC
II-restricted TCRs (Yang and Baltimore, 2005; Zhao et al., 2006b; Ha et al., 2010; Kerkar et al., 2011; Straetemans et al., 2012), and $\gamma \delta$ TCR (Marcu-Malina et al., 2011).

TCRs is generally thought to be restricted to a single epitope (not considering altered peptide ligands). Therefore, the possibility that a single TCR would target multiple cancer epitopes simultaneously would be advantageous. In that regard, an $\alpha \beta T C R$ targeting originally an HLA-A0201-restricted MAGE-A3 epitope was recently isolated and interestingly, it demonstrated reactivity against multiple MAGE epitopes (Chinnasamy et al., 2011).

Additionally and beyond our present scope, it is also possible to modify T-cells to express genes other than those encoding a TCR to redirect T-cell function. These include antibody-based chimeric-antigen receptor (CAR) and other genes to modulate the quality of transduced T-cells (reviewed in Kershaw etal., 2005; Jena et al., 2010; Kohn et al., 2011; Merhavi-Shoham et al., 2012). Another approach for the direction of T-cell specificity was reported lately and is based on bi-specific molecules termed immune-mobilizing monoclonal TCRs against cancer (ImmTACs; Liddy et al., 2012). These newly developed reagents comprise an scFv specific for CD3 (T-cell binding moiety) and a high-affinity cancer-specific TCR (tumor targeting moiety) and were shown to mediate tumor recognition and killing both in vitro and in vivo (Liddy et al., 2012).

\section{WHICH CELL TO ENGINEER?}

One of the basic assumptions when it comes to TCR engineering for cancer treatment is that since malignant cells ought to present their tumor antigens via the MHC class I molecules, the appropriate effector cells to be genetically modified ought to be $\mathrm{CD} 8^{+}$ T lymphocytes. Nonetheless, due to the complexity of the acquired immune system and the different T-cell functional subsets, recent work has been devoted to the importance of the type/subset of T-cells to be adoptively transferred.

While they represent a minority of the circulating lymphocytes, $\gamma \delta$ T-cells have the advantage of expressing TCR chains that apparently do not pair with $\alpha \beta$ TCR chains (Saito et al., 1988). Thus, the use of these cells represents an interesting possibility to prevent the mispairing of the naturally expressed TCR chains with the exogenous one (van der Veken et al., 2006). Bispecific T-cells represent another possible option (reviewed in Marr et al., 2012); for example, virus-specific cells (specific for EBV, CMV or Influenza) can be engineered to express an additional receptor to target tumor cells (Rossig et al., 2002; Murphy etal., 2007; Pule etal., 2008; van der Veken et al., 2009). The use of these cells may considerably reduce off-target effects as these cells have a defined specificity and can provide protection from latent viruses during the immunosuppressed phase prior to adoptive transfer. In addition, the continuous expression of viral antigens following initial infection (such as in the case of EBV) may provide constant stimulation leading to increased persistence (Pule et al., 2008).

We and others have also attempted at modifying precursor cells such as hematopoietic stem cells (HSCs; van Lent et al., 2007; Zhao et al., 2007b), or more recently induced pluripotent stem cells (iPS; Lei et al., 2011), to express a TCR and to be further differentiated into T-cells using, for example, the OP9-DL1 system. Their 
plasticity, differentiation capability into many T-cell subsets, and the possible increased potential to persist in the host (correlated with clinical response; Robbins et al., 2004; Morgan et al., 2006) represent a formidable advantage over peripheral T-cells and it was shown that such modified cells demonstrate anti-tumor function in vivo (Alajez et al., 2005; Yang and Baltimore, 2005; Ha et al., 2010). However, one has to bear in mind that a major drawback lies with their possible transformation induced by retroviral vectors (Hacein-Bey-Abina et al., 2003), though the latter might be circumvented using lentiviral- or transposon-based platforms.

Another interesting option is the use of certain subsets of differentiated T-cells. Following activation, naïve T-cells can turn into effector cells, effector memory or central memory cells. T-cell populations derived from the latter were shown to be exquisitely persistent over time, to further differentiate into both effector and central memory in vivo, with adequate response to antigenic challenge, both in a macaque model (Berger et al., 2008) and more recently for human virus-specific cells in immunodeficient mice (Wang et al., 2011). In regard to TCR-transduced cells, these cells generated ex vivo exhibit mainly a CD62L $\mathrm{L}^{+} / \mathrm{CD} 45 \mathrm{RO}^{+}$phenotype similar to central memory T-cells (Yang et al., 2011). Still, Hinrichs et al. (2009, 2011) showed that TCR-transduced naïve T lymphocytes display increased transgene expression and proliferation compared to memory cells. Muranski et al. (2011) also found that Th17-polarized CD4+ T-cells demonstrate enhanced anti-tumor function, resistance to apoptosis and persistence following adoptive transfer with stem-cell like multipotency signature. The role of Th17 cells in mediating tumor regression was also recently highlighted in a study dealing with the identification of tumor antigens able to mediate tumor regression following immunization (Pulido et al., 2012). Interestingly, Gattinoni et al. (2011) recently identified a subset of T-cells $\left(\mathrm{CD} 45 \mathrm{RO}^{-}, \mathrm{CCR}^{+}, \mathrm{CD} 4 \mathrm{RA}{ }^{+}, \mathrm{CD} 2 \mathrm{~L}^{+}\right.$, $\mathrm{CD}_{27}^{+}, \mathrm{CD}_{2} 8^{+}$, and IL-7R $\left.\alpha^{+}\right)$that are endowed with both naïve and memory properties which they termed T memory stem cells $\left(\mathrm{T}_{\mathrm{scm}}\right)$. This fascinating subset seems more potent in ACT settings than naïve, central, or effector memory $\mathrm{T}$ lymphocytes. Despite their rarity, this type of cells can be generated in vitro by stimulating naïve T-cells in the presence of TWS119, a Wnt pathway activator (Gattinoni et al., 2009, 2011) and based on their potential, these cells might provide a promising subset to be TCR gene engineered, which would demonstrate increased reactivity and persistence over time in patients.

\section{SAFETY ISSUES}

Notwithstanding classical gene therapy-related issues that some of them will be discussed below, manipulating the immune system and often bypassing tolerance mechanisms can generate immune toxicities. Previous works have shown that the transfer of tumor antigen-specific T-cells can cause autoimmune manifestations such as ocular toxicity (Palmer et al., 2008) or systemic autoimmunity (Rosenberg et al., 1988) and this subject has been thoroughly reviewed in Amos et al. (2011).

Still, one the obvious advantages of the use of TCR-engineered cells in the published clinical trials and pre-clinical studies is their autologous origin, which certainly eases their engraftment and long-term persistence. Nevertheless, the expression of transgenes mainly from xenogenic provenance (e.g., murine TCRs or virus-derived 2A peptides) might trigger immunogenicity. Davis et al. (2010) showed that a little less than a quarter of the patients administered T-cells expressing fully murine TCRs (specific for a human pMHC complex) indeed developed antibodies directed essentially to the TCR-variable regions. However this response was not associated with the level of transduced cell persistence or response to therapy.

A comprehensive study showed that 9 years following gene modification of T-cells with a retrovirally expressed transgene, these cells demonstrated stable gene expression profiles and phenotype with no evidence of clonal selection (Recchia et al., 2006). Additionally, it seems so far that no off-target or GVH disorders were observed in patients treated at the Surgery branch (NCI) in seven different TCR-gene transfer clinical protocols (three of which made use of murine TCR that preferentially pair; Park et al., 2011). As quoted above, no replication competent viruses occurrence was observed in hundreds of patients treated with retrovirally engineered T-cells (Bear et al., 2012).

Nevertheless, one has to bear in mind the possible risks associated with this kind of gene therapy such as reactivity to normal tissues expressing the targeted antigen (Johnson et al., 2009; Parkhurst et al., 2011a), possible newly generated specificities associated with TCR mispairing (Bendle et al., 2010; van Loenen et al., 2010), and insertional mutagenesis. Several approaches have been developed to readily eliminate engineered T-cells in case such adverse events take place. These include in part the inclusion of suicide genes (Morgan, 2012) such as a inducible Caspase 9 molecular switch (Straathof et al., 2005; de Witte et al., 2008; Di Stasi et al., 2011) or Herpes Simplex Virus thymidine kinase (HSV-TK; Bonini et al., 1997) in the vector and subsequent triggering of cellular death using a chemical inducer of dimerization (CID) or Ganciclovir, respectively. It is also possible to deplete in vivo TCR-expressing $\mathrm{T}$-cells using antibodies directed against specific tags (such as c-myc or HA), provided the cDNA sequences encoding these peptide tags are added to the $5^{\prime}$-end of the gene(s) encoding the TCR chains (Kieback et al., 2008). In addition, this particular TCR-tagging strategy saves the need to include an additional (suicide) gene in the vector construct.

\section{BEYOND CANCER: TCR-GENE TRANSFER FOR OTHER DISORDERS}

The immune system in general, and T-cells in particular, have been shown to be critically involved both in host defense and unfortunately, in immunopathologies (Morris and Allen, 2012). Thus, the genetic modification of T lymphocytes can provide an attractive way to alter or redirect the immune response in order to target pathogens or remedy to certain $\mathrm{T}$ cell-linked pathologies (Table 1).

Amongst T-cells, the Treg subset is important for the immunomodulation of self-reactivity, especially in the case of autoimmune disorders. It is possible to generate antigenspecific Tregs by gene transfer and defined T-cells with regulatory activity, in order to treat autoimmune disease. Several groups showed that co-transduction of T-cells with FOXP3 and specific TCR created $\mathrm{T}$ regulatory cells that were able to suppress arthritis in different models (Fujio et al., 2006; Wright et al., 2009), for example, by reduction of Th17 cells and decrease of 
Table 1 | Use of TCR-gene transfer for non-neoplastic diseases.

\begin{tabular}{lll}
\hline Condition & Disorder/Pathogen & References \\
\hline Autoimmunity & Arthritis & Fujio et al. (2006) \\
& & Wright et al. (2009) \\
& Systemic autoimmune & Fujio et al. (2004) \\
& disease & \\
Viral infection & Cytomegalovirus (CMV) & Schub et al. (2009) \\
& Epstein-Barr virus (EBV) & Schaft et al. (2006b) \\
& & Hart etal. (2008) \\
& Hepatitis B virus (HBV) & Gehring et al. (2011) \\
& Hepatitis C virus (HCV) & Zhang et al. (2010) \\
& Human immunodeficiency & Cooper etal. (2000) \\
& virus (HIV) & Ueno et al. (2004) \\
& & Varela-Rohena etal. (2008) \\
& Human papilloma virus & Scholten etal. (2005, 2011) \\
& (HPV) & \\
Influenza virus & Kessels etal. (2001) \\
infection & Mycobacterium & Luo et al. (2011) \\
\hline & tuberculosis & \\
\hline
\end{tabular}

bone destruction (Wright et al., 2009). Still in this study, TCRredirected natural Tregs showed a better therapeutic potential than FOXP3-transduced cells. In addition, redirected regulatory $\mathrm{T}$-cells specific for nucleosome antigen were shown to suppress a systemic autoimmune disease in a mouse model (Fujio et al., 2004).

TCR-gene transfer approaches could also be implemented for the redirection of T-cell response against HIV. For example, Cooper etal. (2000) showed more than a decade ago that Tcells can be transduced with a GAG-specific TCR and target cells displaying the relevant epitope. Other HIV antigens were also targeted similarly by TCR-transduced T-cells specific for POL. The engineered lymphocytes showed potent inhibitory activity against HIV-1 replication in vitro and substantial cytotoxic activity and cytokine production triggered by either epitope-pulsed or infected with HIV-1 target cells (the functional phenotype was similar to those of the parental CTL clone) (Ueno et al., 2004). Using an affinity-enhanced codon-optimized GAG-specific TCR, Varela-Rohena et al. (2008) were able to demonstrate very high level of TCR expression that translated into a high sensitivity to the presence of low levels of cognate epitopes on APCs, including escape mutants.

Additionally, recent studies have focused on the possibility of engineering T-cells to recognize other viral epitopes. For example, a CD8-independent HCV-specific TCR was isolated and conferred reactivity to both $\mathrm{CD} 4$ and $\mathrm{CD} 8 \mathrm{~T}$-cells, leading to the recognition of $\mathrm{HCV}^{+}$hepatoma cells (Zhang et al., 2010). Other reports have exemplified the potential of TCR-gene transfer strategy to target CMV (Schub et al., 2009), EBV (Schaft et al., 2006b; Hart et al., 2008), HBV (Gehring et al., 2011), and HPV (Scholten et al., 2005, 2011).
Lately, this approach has been extended to bacterial antigens. As adoptive transfer of Mycobacterium tuberculosis-specific effector T-cells has been shown to confer immunity to infected recipients (Woodworth et al., 2008; Duffy et al., 2009), Luo et al. (2011) aimed at adapting TCR-gene transfer approach to generate anti-bacterial immunity. They isolated M. tuberculosis $38-\mathrm{kDa}$ antigen specific HLA class I and class II-restricted TCRs and subsequently minimally murinized their constant regions (Bialer et al., 2010; Sommermeyer and Uckert, 2010) to enhance their expression and function. When introduced in $\mathrm{CD} 8^{+}$and $\mathrm{CD} 4^{+} \mathrm{T}$-cells, respectively, these TCRs where shown to trigger specific cytokine secretion by T-cells in co-culture with antigen-pulsed DCs, as well as cell-mediated cytotoxicity (by the $\mathrm{CD} 8^{+}$population) (Luo et al., 2011).

\section{CONCLUSIONS AND FUTURE DIRECTIONS}

TCR-gene modifications of primary human T-cells have demonstrated over the past decade significant achievements, the most important one being its encouraging translation from bench to bedside. In the past few years, successful gene-therapy studies have renewed hopes with regard to the ability to genetically modify patient cells for therapeutic purposes (Kay, 2011; Sheridan, 2011). Unlike for monogenic diseases, the broader implementation of TCR-gene transfer as a semi-personalized medicine approach would require the isolation and the characterization of multiple TCRs, due to HLA polymorphism and the variety of tumor antigens that would need to be targeted. The nature of the antigen, its exquisite expression by the tumor, but more importantly, its immunogenicity and its capacity to evoke efficient tumor response will be a crucial determinant for the success of this kind of therapy. More needs to be understood about antigen immunodominance and the kinetics and dynamics of tumor antigen expression, even if impressive tumor regressions were observed in patients treated with monospecific engineered Tcells (Morgan et al., 2006; Johnson et al., 2009; Park et al., 2011; Robbins et al., 2011). In this regard, extensive screening of tumor reactive T-cells such as TILs may provide valuable information about the specificity of the anti-tumor T-cell response in cancer patients (Andersen et al., 2012). Additionally, the functional characterization of the ability of antigens to mediate tumor regression will provide critical insight as to which epitope(s) TCRs should be specific for (Pulido et al., 2012). Needless to say that the widespread implementation of such "off-the shelf" genetherapy protocols will benefit from the development of approaches for in vivo infection as well as from a better understanding of the cell selection and conditioning process. The combination of newly immunomodulating agents and/or vaccination strategy may improve the clinical response rates (Mellman et al., 2011). Overall, the ability of redirecting the specificity of T-cells genetically holds great promise for the immunotherapy of cancer and other diseases.

\section{ACKNOWLEDGMENTS}

This work was supported by the Israel Science Foundation (773/08) and by the Marie-Curie International Reintegration Grant (224851) from the European Community. 


\section{REFERENCES}

Aarnoudse, C. A., Kruse, M., Konopitzky, R., Brouwenstijn, N., and Schrier, P. I. (2002). TCR reconstitution in Jurkat reporter cells facilitates the identification of novel tumor antigens by cDNA expression cloning. Int. J. Cancer 99, 7-13.

Aggen, D. H., Chervin, A. S., Schmitt, T. M., Engels, B., Stone, J. D., Richman, S. A., Piepenbrink, K. H., Baker, B. M., Greenberg, P. D., Schreiber, H., and Kranz, D. M. (2012). Single-chain ValphaVbeta T-cell receptors function without mispairing with endogenous TCR chains. Gene Ther. 19, 365-374.

Ahmadi, M., King, J. W., Xue, S. A., Voisine, C., Holler, A., Wright, G. P., Waxman, J., Morris, E., and Stauss, H. J. (2011). CD3 limits the efficacy of TCR gene therapy in vivo. Blood 118, 3528-3537.

Alajez, N. M., Schmielau, J., Alter, M. D., Cascio, M., and Finn, O. J. (2005). Therapeutic potential of a tumor-specific, MHC-unrestricted $\mathrm{T}$-cell receptor expressed on effector cells of the innate and the adaptive immune system through bone marrow transduction and immune reconstitution. Blood 105, 45834589.

Alli, R., Zhang, Z. M., Nguyen, P., Zheng, J. J., and Geiger, T. L. (2011). Rational design of $\mathrm{T}$ cell receptors with enhanced sensitivity for antigen. PLOS ONE 6, e18027. doi: 10.1371/journal.pone.0018027

Almasbak, H., Rian, E., Hoel, H. J., Pule, M., Walchli, S., Kvalheim, G., Gaudernack, G., and Rasmussen, A. M. (2011). Transiently redirected T cells for adoptive transfer. Cytotherapy 13, 629-640.

Amir, A. L., van der Steen, D. M., van Loenen, M. M., Hagedoorn, R. S., de Boer, R., Kester, M. D., de Ru, A. H., Lugthart, G. J., van Kooten, C., Hiemstra, P. S., Jedema, I., Griffioen, M., van Veelen, P. A., Falkenburg, J. H., and Heemskerk, M. H. (2011). PRAME-specific Allo-HLArestricted $T$ cells with potent antitumor reactivity useful for therapeutic T-cell receptor gene transfer. Clin. Cancer Res. 17, 5615-5625.

Amos, S. M., Duong, C. P., Westwood, J. A., Ritchie, D. S., Junghans, R. P., Darcy, P. K., and Kershaw, M. H. (2011). Autoimmunity associated with immunotherapy of cancer. Blood 118, 499-509.

Andersen, R. S., Thrue, C. A., Junker, N., Lyngaa, R., Donia, M., Ellebaek, E., Svane, I. M., Schumacher, T. N., Thor, S. P., and Hadrup, S. R. (2012).
Dissection of T-cell antigen specificity in human melanoma. Cancer Res. 72, 1642-1650.

Bear, A. S., Morgan, R. A., Cornetta, K., June, C. H., Binder-Scholl, G., Dudley, M. E., Feldman, S. A., Rosenberg, S. A., Shurtleff, S. A., Rooney, C. M., Heslop, H. E., and Dotti, G. (2012). Replication-competent retroviruses in gene-modified $\mathrm{T}$ cells used in clinical trials: is it time to revise the testing requirements? Mol. Ther 20, 246-249.

Bendle, G. M., Linnemann, C., Hooijkaas, A. I., Bies, L., de Witte, M. A., Jorritsma, A., Kaiser, A. D., Pouw, N., Debets, R., Kieback, E., Uckert, W., Song, J. Y., Haanen, J. B., and Schumacher, T. N. (2010). Lethal graftversus-host disease in mouse models of $\mathrm{T}$ cell receptor gene therapy. Nat. Med. 16, 565-570.

Berger, C., Jensen, M. C., Lansdorp, P. M., Gough, M., Elliott, C., and Riddell, S. R. (2008). Adoptive transfer of effector CD8 $+\mathrm{T}$ cells derived from central memory cells establishes persistent T cell memory in primates. J. Clin. Invest. 118, 294-305.

Berger, C., Turtle, C. J., Jensen, M. C., and Riddell, S. R. (2009). Adoptive transfer of virus-specific and tumorspecific T cell immunity. Curr. Opin. Immunol. 21, 224-232.

Bialer, G., Horovitz-Fried, M., Ya'acobi, S., Morgan, R. A., and Cohen, C. J. (2010). Selected murine residues endow human TCR with enhanced tumor recognition. J. Immunol. 184, 6232-6241.

Birkholz, K., Hofmann, C., Hoyer, S., Schulz, B., Harrer, T., Kampgen, E., Schuler, G., Dorrie, J., and Schaft, N. (2009). A fast and robust method to clone and functionally validate T-cell receptors. J. Immunol. Methods 346, 45-54.

Bonini, C., Ferrari, G., Verzeletti, S., Servida, P., Zappone, E., Ruggieri, L., Ponzoni, M., Rossini, S., Mavilio, F., Traversari, C., and Bordignon, C. (1997). HSV-TK gene transfer into donor lymphocytes for control of allogeneic graft-versus-leukemia. Science 276, 1719-1724.

Borbulevych, O. Y., Santhanagopolan, S. M., Hossain, M., and Baker, B. M. (2011). TCRs used in cancer gene therapy cross-react with MART1/Melan-A tumor antigens via distinct mechanisms. J. Immunol. 187, 2453-2463.

Boria, I., Cotella, D., Dianzani, I., Santoro, C., and Sblattero, D. (2008). Primer sets for cloning the human repertoire of $\mathrm{T}$ cell receptor variable regions. BMC Immunol. 9, 50. doi: 10.1186/1471-2172-9-50
Burns, W. R., Zheng, Z., Rosenberg, S. A., and Morgan, R. A. (2009). Lack of specific gamma-retroviral vector long terminal repeat promoter silencing in patients receiving genetically engineered lymphocytes and activation upon lymphocyte restimulation. Blood 114, 2888-2899.

Cavalieri, S., Cazzaniga, S., Geuna, M., Magnani, Z., Bordignon, C. Naldini, L., and Bonini, C. (2003). Human $\mathrm{T}$ lymphocytes transduced by lentiviral vectors in the absence of TCR activation maintain an intact immune competence. Blood 102, 497-505.

Chinnasamy, N., Wargo, J. A., Yu, Z., Rao, M., Frankel, T. L., Riley, J. P., Hong, J. J., Parkhurst, M. R., Feldman, S. A., Schrump, D. S., Restifo, N. P., Robbins, P. F., Rosenberg, S. A., and Morgan, R. A. (2011). A TCR targeting the HLA $A^{*}$ 0201-restricted epitope of MAGEA3 recognizes multiple epitopes of the MAGE-A antigen superfamily in several types of cancer. J. Immunol. 186, 685-696.

Chlewicki, L. K., Holler, P. D., Monti, B. C., Clutter, M. R., and Kranz D. M. (2005). High-affinity, peptidespecific $\mathrm{T}$ cell receptors can be generated by mutations in CDR1, CDR2 or CDR3. J. Mol. Biol. 346, 223-239.

Chung, S., Wucherpfennig, K. W., Friedman, S. M., Hafler, D. A., and Strominger, J. L. (1994). Functional threedomain single-chain T-cell receptors Proc. Natl. Acad. Sci. U.S.A. 91, 12654-12658.

Circosta, P., Granziero, L., Follenzi, A., Vigna, E., Stella, S., Vallario, A., Elia, A. R., Gammaitoni, L., Vitaggio, K. Orso, F., Geuna, M., Sangiolo, D. Todorovic, M., Giachino, C., and Cignetti, A. (2009). T cell receptor (TCR) gene transfer with lentiviral vectors allows efficient redirection of tumor specificity in naive and memory $\mathrm{T}$ cells without prior stimulation of endogenous TCR. Hum. Gene Ther. 20, 1576-1588.

Clay, T. M., Custer, M. C., Sachs, J., Hwu, P., Rosenberg, S. A. and Nishimura, M. I. (1999). Efficient transfer of a tumor antigenreactive TCR to human peripheral blood lymphocytes confers antitumor reactivity. J. Immunol. 163 507-513.

Cohen, C. J., Li, Y. F., El Gamil, M., Robbins, P. F., Rosenberg, S. A., and Morgan, R. A. (2007). Enhanced antitumor activity of $\mathrm{T}$ cells engineered to express T-cell receptors with a second disulfide bond. Cancer Res. 67, 3898-3903.
Cohen, C. J., Zhao, Y., Zheng, Z., Rosenberg, S. A., and Morgan, R. A. (2006). Enhanced antitumor activity of murine-human hybrid T-cell receptor (TCR) in human lymphocytes is associated with improved pairing and TCR/CD3 stability. Cancer Res. 66, 8878-8886.

Cohen, C. J., Zheng, Z., Bray, R., Zhao, Y., Sherman, L. A., Rosenberg, S. A., and Morgan, R. A. (2005). Recognition of fresh human tumor by human peripheral blood lymphocytes transduced with a bicistronic retroviral vector encoding a murine anti-p53 TCR. J. Immunol. 175, 5799-5808.

Cooper, L. J., Kalos, M., Lewinsohn, D. A., Riddell, S. R., and Greenberg, P. D. (2000). Transfer of specificity for human immunodeficiency virus type 1 into primary human $\mathrm{T}$ lymphocytes by introduction of $\mathrm{T}$-cell receptor genes. J. Virol. 74, 8207-8212.

Daniels, M. A., Hogquist, K. A., and Jameson, S. C. (2002). Sweet ' $n$ ' sour: the impact of differential glycosylation on $\mathrm{T}$ cell responses. Nat. Immunol. 3, 903-910.

Davis, J. L., Theoret, M. R., Zheng, Z., Lamers, C. H., Rosenberg, S. A., and Morgan, R. A. (2010). Development of human anti-murine $\mathrm{T}$-cell receptor antibodies in both responding and nonresponding patients enrolled in TCR gene therapy trials. Clin. Cancer Res. 16, 5852-5861.

Dembic, Z., Haas, W., Weiss, S., McCubrey, J., Kiefer, H., von Boehmer, H., and Steinmetz, M. (1986). Transfer of specificity by murine alpha and beta $\mathrm{T}$-cell receptor genes. Nature 320, 232-238.

de Witte, M. A., Jorritsma, A., Swart, E., Straathof, K. C., de Punder, K., Haanen, J. B., Rooney, C. M., and Schumacher, T. N. (2008). An inducible caspase 9 safety switch can halt cell therapy-induced autoimmune disease. J. Immunol. 180, 6365-6373.

Di Stasi, A., Tey, S. K., Dotti, G., Fujita, Y., Kennedy-Nasser, A., Martinez, C., Straathof, K., Liu, E., Durett, A. G., Grilley, B., Liu, H., Cruz, C. R., Savoldo, B., Gee, A. P., Schindler, J., Krance, R. A., Heslop, H. E., Spencer, D. M., Rooney, C. M., and Brenner, M. K. (2011). Inducible apoptosis as a safety switch for adoptive cell therapy. N. Engl. J. Med. 365, 1673-1683.

Duffy, D., Dawoodji, A., Agger, E. M., Andersen, P., Westermann, J., and Bell, E. B. (2009). Immunological memory transferred with CD4 $\mathrm{T}$ cells specific for tuberculosis antigens Ag85B-TB10.4: persisting antigen enhances protection. PLoS ONE 4, e8272. doi: 10.1371/journal.pone. 0008272 
Feuchtinger, T., Matthes-Martin, S., Richard, C., Lion, T., Fuhrer, M., Hamprecht, K., Handgretinger, R., Peters, C., Schuster, F. R., Beck, R., Schumm, M., Lotfi, R., Jahn, G., and Lang, P. (2006). Safe adoptive transfer of virus-specific T-cell immunity for the treatment of systemic adenovirus infection after allogeneic stem cell transplantation. Br. J. Haematol. 134, 64-76.

Frankel, T. L., Zhang, L., Burns, W. R., Zheng, Z., and Morgan, R. A. (2011). The position of the AUG start codon in MFG-based gammaretroviral vectors has a dramatic effect on translation-dependent protein expression. J. Gene Med. 13, 478-486.

Frecha, C., Levy, C., Cosset, F. L., and Verhoeyen, E. (2010). Advances in the field of lentivector-based transduction of $\mathrm{T}$ and $\mathrm{B}$ lymphocytes for gene therapy. Mol. Ther. 18, 1748-1757.

Fujio, K., Okamoto, A., Araki, Y., Shoda, H., Tahara, H., Tsuno, N. H., Takahashi, K., Kitamura, T., and Yamamoto, K. (2006). Gene therapy of arthritis with TCR isolated from the inflamed paw. J. Immunol. 177, 8140-8147.

Fujio, K., Okamoto, A., Tahara, H., Abe, M., Jiang, Y., Kitamura, T., Hirose, S., and Yamamoto, K. (2004). Nucleosome-specific regulatory $\mathrm{T}$ cells engineered by triple gene transfer suppress a systemic autoimmune disease. J. Immunol. 173 , 2118-2125.

Fujita, Y., Rooney, C. M., and Heslop, H. E. (2008). Adoptive cellular immunotherapy for viral diseases. Bone Marrow Transplant. 41, 193-198.

Gattinoni, L., Klebanoff, C. A., Palmer, D. C., Wrzesinski, C., Kerstann, K. Yu, Z., Finkelstein, S. E., Theoret, M. R., Rosenberg, S. A., and Restifo, N. P. (2005). Acquisition of full effector function in vitro paradoxically impairs the in vivo antitumor efficacy of adoptively transferred CD8+ T cells. J Clin. Invest. 115, 1616-1626.

Gattinoni, L., Lugli, E., Ji, Y., Pos, Z., Paulos, C. M., Quigley, M. F., Almeida, J. R., Gostick, E., Yu, Z., Carpenito, C., Wang, E., Douek, D. C., Price, D. A., June, C. H., Marincola, F. M., Roederer, M., and Restifo, N. P. (2011). A human memory T cell subset with stem cell-like properties. Nat. Med. 17, 1290-1297.

Gattinoni, L., Zhong, X. S., Palmer, D. C., Ji, Y., Hinrichs, C. S., Yu, Z., Wrzesinski, C., Boni, A., Cassard, L., Garvin, L. M., Paulos, C.
M., Muranski, P., and Restifo, N. P. (2009). Wnt signaling arrests effector $\mathrm{T}$ cell differentiation and generates CD8+ memory stem cells. Nat. Med. $15,808-813$.

Gehring, A. J., Xue, S. A., Ho, Z. Z., Teoh, D., Ruedl, C., Chia, A., Koh, S., Lim, S. G., Maini, M. K., Stauss, H., and Bertoletti, A. (2011). Engineering virus-specific $\mathrm{T}$ cells that target HBV infected hepatocytes and hepatocellular carcinoma cell lines. J. Hepatol. 55, 103-110.

Ghattas, I. R., Sanes, J. R., and Majors, J. E. (1991). The encephalomyocarditis virus internal ribosome entry site allows efficient coexpression of two genes from a recombinant provirus in cultured cells and in embryos. Mol. Cell Biol. 11, 5848-5859.

Govers, C., Sebestyen, Z., Berrevoets, C. Venselaar, H., and Debets, R. (2011). $\mathrm{T}$ cell receptor fused to CD3zeta: transmembrane domain of CD3zeta prevents TCR mis-pairing, whereas complete CD3zeta directs functional TCR expression. Open Gene Ther. J. 4, 11-22.

Govers, C., Sebestyen, Z., Coccoris, M., Willemsen, R. A., and Debets, R. (2010). T cell receptor gene therapy: strategies for optimizing transgenic TCR pairing. Trends Mol. Med. 16, 77-87.

Ha, S. P., Klemen, N. D., Kinnebrew, G. H., Brandmaier, A. G., Marsh, J., Hangoc, G., Palmer, D. C., Restifo, N. P., Cornetta, K., Broxmeyer, H. E. and Touloukian, C. E. (2010). Transplantation of mouse HSCs genetically modified to express a CD4-restricted TCR results in long-term immunity that destroys tumors and initiates spontaneous autoimmunity. J. Clin. Invest 120, 4273-4288.

Hacein-Bey-Abina, S., von Kalle, C., Schmidt, M., Le Deist, F., Wulffraat, N., McIntyre, E., Radford, I., Villeval, J. L., Fraser, C. C., Cavazzana-Calvo, M., and Fischer, A. (2003). A serious adverse event after successful gene therapy for X-linked severe combined immunodeficiency. N. Engl. J. Med. 348, 255-256.

Haga-Friedman, A., Horovitz-Fried, M. and Cohen, C. J. (2012). Incorporation of transmembrane hydrophobic mutations in the TCR enhance its surface expression and $\mathrm{T}$ cell functional avidity. J. Immunol. 188, 5538-5546.

Hart, D. P., Xue, S. A., Thomas, S., Cesco-Gaspere, M., Tranter, A., Willcox, B., Lee, S. P., Steven, N., Morris, E. C., and Stauss, H. J. (2008). Retroviral transfer of a dominant TCR prevents surface expression of a large proportion of the endogenous TCR repertoire in human $\mathrm{T}$ cells. Gene Ther. 15, 625-631.

Hawkins, R. E., Gilham, D. E., Debets, R., Eshhar, Z., Taylor, N., Abken, H., Schumacher, T. N., and ATTACK Consortium (2010). Development of adoptive cell therapy for cancer: a clinical perspective. Hum. Gene Ther. 21, 665-672.

Heemskerk, M. H., Hagedoorn, R. S., van der Hoorn, M. A., van der Veken, L. T., Hoogeboom, M., Kester, M. G., Willemze, R., and Falkenburg, J. H. (2007). Efficiency of T-cell receptor expression in dual-specific $\mathrm{T}$ cells is controlled by the intrinsic qualities of the TCR chains within the TCR-CD3 complex. Blood 109, 235-243.

Heemskerk, M. H., Hoogeboom, M., de Paus, R. A., Kester, M. G., van der Hoorn, M. A., Goulmy, E., Willemze, R., and Falkenburg, J. H. (2003) Redirection of antileukemic reactivity of peripheral T lymphocytes using gene transfer of minor histocompatibility antigen HA-2-specific T-cell receptor complexes expressing a conserved alpha joining region. Blood 102, 3530-3540.

Heslop, H. E., Ng, C. Y., Li, C., Smith, C. A., Loftin, S. K., Krance, R. A., Brenner, M. K., and Rooney, C. M. (1996). Long-term restoration of immunity against Epstein-Barr virus infection by adoptive transfer of gene-modified virus-specific $\mathrm{T}$ lymphocytes. Nat. Med. 2, 551-555.

Hinrichs, C. S., Borman, Z. A., Cassard, L., Gattinoni, L., Spolski, R., Yu, Z., Sanchez-Perez, L., Muranski, P., Kern, S. J., Logun, C., Palmer, D. C., Ji, Y., Reger, R. N., Leonard, W. J., Danner, R. L., Rosenberg, S. A., and Restifo, N. P. (2009). Adoptively transferred effector cells derived from naive rather than central memory CD8 $+\mathrm{T}$ cells mediate superior antitumor immunity. Proc. Natl. Acad. Sci. U.S.A. 106, 17469-17474.

Hinrichs, C. S., Borman, Z. A., Gattinoni, L., Yu, Z., Burns, W. R. Huang, J., Klebanoff, C. A., Johnson, L. A., Kerkar, S. P., Yang, S., Muranski, P., Palmer, D. C., Scott, C. D., Morgan, R. A., Robbins, P. F., Rosenberg, S. A., and Restifo, N. P. (2011). Human effector CD8+ T cells derived from naive rather than memory subsets possess superior traits for adoptive immunotherapy. Blood 117, 808-814.

Holler, P. D., Holman, P. O., Shusta, E. V., O'Herrin, S., Wittrup, K. D., and Kranz, D. M. (2000). In vitro evolution of a $\mathrm{T}$ cell receptor with high affinity for peptide/MHC.
Proc. Natl. Acad. Sci. U.S.A. 97, 5387-5392.

Huang, X., Wilber, A. C., Bao, L., Tuong, D., Tolar, J., Orchard, P. J., Levine, B. L., June, C. H., McIvor, R. S., Blazar, B. R., and Zhou, X. (2006). Stable gene transfer and expression in human primary $\mathrm{T}$ cells by the Sleeping Beauty transposon system. Blood 107, 483-491.

Ivics, Z., Hackett, P. B., Plasterk, R. H., and Izsvak, Z. (1997). Molecular reconstruction of Sleeping Beauty, a Tcl-like transposon from fish, and its transposition in human cells. Cell 91, 501-510.

Jena, B., Dotti, G., and Cooper, L. J. (2010). Redirecting T-cell specificity by introducing a tumor-specific chimeric antigen receptor. Blood 116 , 1035-1044.

Jin, Z., Maiti, S., Huls, H., Singh, H., Olivares, S., Mates, L., Izsvak, Z., Ivics, Z., Lee, D. A., Champlin, R. E., and Cooper, L. J. (2011). The hyperactive Sleeping Beauty transposase SB100X improves the genetic modification of $\mathrm{T}$ cells to express a chimeric antigen receptor. Gene Ther. 18, 849-856.

Johnson, L. A., Heemskerk, B., Powell, D. J. Jr., Cohen, C. J., Morgan, R. A., Dudley, M. E., Robbins, P. F., and Rosenberg, S. A. (2006). Gene transfer of tumor-reactive TCR confers both high avidity and tumor reactivity to nonreactive peripheral blood mononuclear cells and tumorinfiltrating lymphocytes. J. Immunol. 177, 6548-6559.

Johnson, L. A., Morgan, R. A., Dudley, M. E., Cassard, L., Yang, J. C., Hughes, M. S., Kammula, U. S., Royal, R. E., Sherry, R. M., Wunderlich, J. R., Lee, C. C., Restifo, N. P., Schwarz, S. L., Cogdill, A. P., Bishop, R. J., Kim, H., Brewer, C. C., Rudy, S. F., Vanwaes, C., Davis, J. L., Mathur, A., Ripley, R. T., Nathan, D. A., Laurencot, C. M., and Rosenberg, S. A. (2009). Gene therapy with human and mouse T-cell receptors mediates cancer regression and targets normal tissues expressing cognate antigen. Blood 114, 535-546.

Jones, S., Peng, P. D., Yang, S., Hsu, C., Cohen, C. J., Zhao, Y., Abad, J., Zheng, Z., Rosenberg, S. A., and Morgan, R. A. (2009). Lentiviral vector design for optimal T cell receptor gene expression in the transduction of peripheral blood lymphocytes and tumorinfiltrating lymphocytes. Hum. Gene Ther. 20, 630-640.

Jorritsma, A., Gomez-Eerland, R., Dokter, M., van de, K. W., Zoet, Y. M., Doxiadis, I. I., Rufer, N., Romero, P., Morgan, R. A., Schumacher, T. 
N., and Haanen, J. B. (2007). Selecting highly affine and well-expressed TCRs for gene therapy of melanoma. Blood 110, 3564-3572.

Kay, M. A. (2011). State-of-the-art gene-based therapies: the road ahead. Nat. Rev. Genet. 12, 316-328.

Kerkar, S. P., Sanchez-Perez, L., Yang, S., Borman, Z. A., Muranski, P., Ji, Y., Chinnasamy, D., Kaiser, A. D. Hinrichs, C. S., Klebanoff, C. A., Scott, C. D., Gattinoni, L., Morgan, R. A., Rosenberg, S. A., and Restifo, N. P. (2011). Genetic engineering of murine CD8(+) and CD4(+) T cells for preclinical adoptive immunotherapy studies. J. Immunother. 34, 343-352.

Kershaw, M. H., Teng, M. W., Smyth, M. J., and Darcy, P. K. (2005). Supernatural T cells: genetic modification of T cells for cancer therapy. Nat. Rev. Immunol. 5, 928-940.

Kessels, H. W., Wolkers, M. C., van den Boom, M. D., van der Valk, M. A., and Schumacher, T. N. (2001). Immunotherapy through TCR gene transfer. Nat. Immunol. 2, 957-961.

Kieback, E., Charo, J., Sommermeyer, D., Blankenstein, T., and Uckert, W. (2008). A safeguard eliminates T cell receptor gene-modified autoreactive $\mathrm{T}$ cells after adoptive transfer. Proc. Natl. Acad. Sci. U.S.A. 105, 623-628.

Kohn, D. B., Dotti, G., Brentjens, R., Savoldo, B., Jensen, M., Cooper, L. J., June, C. H., Rosenberg, S., Sadelain, M., and Heslop, H. E. (2011). CARs on track in the clinic. Mol. Ther. 19 , 432-438.

Kuball, J., Dossett, M. L., Wolfl, M., Ho, W. Y., Voss, R. H., Fowler, C., and Greenberg, P. D. (2007). Facilitating matched pairing and expression of TCR chains introduced into human T cells. Blood 109, 2331-2338.

Kuball, J., Hauptrock, B., Malina, V., Antunes, E., Voss, R. H., Wolfl, M., Strong, R., Theobald, M., and Greenberg, P. D. (2009). Increasing functional avidity of TCR-redirected $\mathrm{T}$ cells by removing defined $\mathrm{N}$ glycosylation sites in the TCR constant domain. J. Exp. Med. 206, 463-475.

Kuball, J., Schmitz, F. W., Voss, R. H., Ferreira, E. A., Engel, R., Guillaume, P., Strand, S., Romero, P., Huber, C., Sherman, L. A., and Theobald, M. (2005). Cooperation of human tumor-reactive CD4+ and CD8+ $\mathrm{T}$ cells after redirection of their specificity by a high-affinity p53A2.1-specific TCR. Immunity 22, 117-129.
Leen, A. M., Myers, G. D., Sili, U., Huls, M. H., Weiss, H., Leung, K. S., Carrum, G., Krance, R. A., Chang, C. C. Molldrem, J. J., Gee, A. P., Brenner, M. K., Heslop, H. E., Rooney, C. M., and Bollard, C. M. (2006). Monoculturederived $\mathrm{T}$ lymphocytes specific for multiple viruses expand and produce clinically relevant effects in immunocompromised individuals. Nat. Med. $12,1160-1166$

Lei, F., Zhao, B., Haque, R., Xiong, X., Budgeon, L., Christensen, N. D., Wu, Y., and Song, J. (2011). In vivo programming of tumor antigenspecific T lymphocytes from pluripotent stem cells to promote cancer immunosurveillance. Cancer Res. 71, 4742-4747.

Leisegang, M., Engels, B., Meyerhuber P., Kieback, E., Sommermeyer, D. Xue, S. A., Reuss, S., Stauss, H., and Uckert, W. (2008). Enhanced functionality of $\mathrm{T}$ cell receptor-redirected $\mathrm{T}$ cells is defined by the transgene cassette. J. Mol. Med. 86, 573-583.

Levine, B. L., Humeau, L. M., Boyer, J., MacGregor, R. R., Rebello, T., Lu, X., Binder, G. K., Slepushkin, V., Lemiale, F., Mascola, J. R., Bushman, F. D., Dropulic, B., and June, C. H. (2006). Gene transfer in humans using a conditionally replicating lentiviral vector. Proc. Natl. Acad. Sci. U.S.A. 103, 17372-17377.

Li, L. P., Lampert, J. C., Chen, X., Leitao, C., Popovic, J., Muller, W. and Blankenstein, T. (2010). Transgenic mice with a diverse human $\mathrm{T}$ cell antigen receptor repertoire. Nat. Med. 16, 1029-1034.

Li, Y., Moysey, R., Molloy, P. E., Vuidepot, A. L., Mahon, T., Baston, E. Dunn, S., Liddy, N., Jacob, J., Jakobsen, B. K., and Boulter, J. M. (2005). Directed evolution of human T-cell receptors with picomolar affinities by phage display. Nat. Biotechnol. 23, 349-354.

Liddy, N., Bossi, G., Adams, K. J., Lissina, A., Mahon, T. M., Hassan, N. J., Gavarret, J., Bianchi, F. C., Pumphrey, N. J., Ladell, K., Gostick, E., Sewell, A. K., Lissin, N. M., Harwood, N. E., Molloy, P. E., Li, Y., Cameron, B. J., Sami, M., Baston, E. E., Todorov, P. T., Paston, S. J., Dennis, R. E., Harper, J. V., Dunn, S. M., Ashfield, R., Johnson, A., McGrath, Y. Plesa, G., June, C. H., Kalos, M., Price, D. A., Vuidepot, A., Williams, D. D., Sutton, D. H., and Jakobsen, B. K. (2012). Monoclonal TCR-redirected tumor cell killing. Nat. Med. 18, 980-987.

Luo, W., Zhang, X. B., Huang, Y. T., Hao, P. P., Jiang, Z. M., Wen, Q.,
Zhou, M. Q., Jin, Q., and Ma, L. (2011). Development of genetically engineered CD4+ and CD8 + T cells expressing TCRs specific for a $\mathrm{M}$. tuberculosis $38-\mathrm{kDa}$ antigen. J. $\mathrm{Mol}$. Med. (Berl) 89, 903-913.

Marcu-Malina, V., Heijhuurs, S., van Buuren, M., Hartkamp, L., Strand, S. Sebestyen, Z., Scholten, K., Martens, A., and Kuball, J. (2011). Redirecting alphabeta $\mathrm{T}$ cells against cancer cells by transfer of a broadly tumorreactive gammadeltaT-cell receptor. Blood 118, 50-59.

Marr, L. A., Gilham, D. E., Campbell, J. D., and Fraser, A. R. (2012). Immunology in the clinic review series; focus on cancer: double trouble for tumours: bi-functional and redirected $\mathrm{T}$ cells as effective cancer immunotherapies. Clin. Exp. Immunol. 167, 216-225.

Mellman, I., Coukos, G., and Dranoff, G. (2011). Cancer immunotherapy comes of age. Nature 480 480-489.

Merhavi-Shoham, E., Haga-Friedman, A., and Cohen, C. J. (2012). Genetically modulating $\mathrm{T}$-cell function to target cancer. Semin. Cancer Biol. 22, 14-22.

Mizuguchi, H., Xu, Z., Ishii-Watabe, A., Uchida, E., and Hayakawa, T (2000). IRES-dependent second gene expression is significantly lower than cap-dependent first gene expression in a bicistronic vector. Mol. Ther. 1 , 376-382.

Mommaas, B., van Halteren, A. G., Pool, J., van der Veken, L., Wieles, B. Heemskerk, M. H., and Goulmy, E. (2005). Adult and cord blood T cells can acquire HA-1 specificity through HA-1 T-cell receptor gene transfer. Haematologica 90, 1415-1421.

Morgan, R. A. (2012). Live and let die: a new suicide gene therapy moves to the clinic. Mol. Ther. 20,11-13.

Morgan, R. A., Dudley, M. E., Wunderlich, J. R., Hughes, M. S., Yang, J. C., Sherry, R. M., Royal, R. E. Topalian, S. L., Kammula, U. S., Restifo, N. P., Zheng, Z., Nahvi, A., de Vries, C. R., Rogers-Freezer, L. J., Mavroukakis, S. A., and Rosenberg, S. A. (2006). Cancer regression in patients after transfer of genetically engineered lymphocytes. Science 314, 126-129.

Morris, G. P., and Allen, P. M. (2012). How the TCR balances sensitivity and specificity for the recognition of self and pathogens. Nat. Immunol. 13, 121-128.

Muranski, P., Borman, Z. A., Kerkar, S. P., Klebanoff, C. A., Ji, Y., SanchezPerez, L., Sukumar, M., Reger, R. N., Yu, Z., Kern, S. J., Roychoudhuri, R.,
Ferreyra, G. A., Shen, W., Durum, S. K., Feigenbaum, L., Palmer, D. C., Antony, P. A., Chan, C. C., Laurence, A., Danner, R. L., Gattinoni, L., and Restifo, N. P. (2011). Th17 cells are long lived and retain a stem celllike molecular signature. Immunity 35, 972-985.

Murphy, A., Westwood, J. A., Brown, L. E., Teng, M. W., Moeller, M., Xu, Y., Smyth, M. J., Hwu, P., Darcy, P. K., and Kershaw, M. H. (2007). Antitumor activity of dual-specific T cells and influenza virus. Cancer Gene Ther. 14, 499-508.

Novellino, L., Castelli, C., and Parmiani, G. (2005). A listing of human tumor antigens recognized by T cells: March 2004 update. Cancer Immunol. Immunother. 54, 187-207.

Okamoto, S., Mineno, J., Ikeda, H., Fujiwara, H., Yasukawa, M., Shiku, H., and Kato, I. (2009). Improved expression and reactivity of transduced tumor-specific TCRs in human lymphocytes by specific silencing of endogenous TCR. Cancer Res. 69, 9003-9011.

Palmer, D. C., Chan, C. C., Gattinoni, L., Wrzesinski, C., Paulos, C. M., Hinrichs, C. S., Powell, D. J. Jr., Klebanoff, C. A., Finkelstein, S. E., Fariss, R. N., Yu, Z., Nussenblatt, R. B., Rosenberg, S. A., and Restifo, N. P. (2008). Effective tumor treatment targeting a melanoma/melanocyte-associated antigen triggers severe ocular autoimmunity. Proc. Natl. Acad. Sci. U.S.A. 105, 8061-8066.

Park, T. S., Rosenberg, S. A., and Morgan, R. A. (2011). Treating cancer with genetically engineered $\mathrm{T}$ cells. Trends Biotechnol. 29, 550-557.

Parkhurst, M. R., Yang, J. C., Langan, R. C., Dudley, M. E., Nathan, D. A., Feldman, S. A., Davis, J. L., Morgan, R. A., Merino, M. J., Sherry, R. M., Hughes, M. S., Kammula, U. S., Phan, G. Q., Lim, R. M., Wank, S. A., Restifo, N. P., Robbins, P. F., Laurencot, C. M., and Rosenberg, S. A. (2011a). T cells targeting carcinoembryonic antigen can mediate regression of metastatic colorectal cancer but induce severe transient colitis. Mol. Ther. 19, 620-626.

Parkhurst, M. R., Yang, J. C., Langan, R. C., Dudley, M. E., Nathan, D. A., Feldman, S. A., Davis, J. L., Morgan, R. A., Merino, M. J., Sherry, R. M., Hughes, M. S., Kammula, U. S., Phan, G. Q., Lim, R. M., Wank, S. A., Restifo, N. P., Robbins, P. F., Laurencot, C. M., and Rosenberg, S. A. (2011b). T cells targeting carcinoembryonic antigen can mediate regression of metastatic colorectal 
cancer but induce severe transient colitis. Mol. Ther. 19, 620-626.

Peng, P. D., Cohen, C. J., Yang, S., Hsu, C., Jones, S., Zhao, Y., Zheng, Z., Rosenberg, S. A., and Morgan, R. A. (2009). Efficient nonviral Sleeping Beauty transposon-based TCR gene transfer to peripheral blood lymphocytes confers antigen-specific antitumor reactivity. Gene Ther. 16, 1042-1049.

Perro, M., Tsang, J., Xue, S. A., Escors, D., Cesco-Gaspere, M., Pospori, C., Gao, L., Hart, D., Collins, M., Stauss, H., and Morris, E. C. (2010). Generation of multi-functional antigenspecific human T-cells by lentiviral TCR gene transfer. Gene Ther. 17, 721-732.

Provasi, E., Genovese, P., Lombardo, A., Magnani, Z., Liu, P. Q., Reik, A., Chu, V., Paschon, D. E., Zhang, L., Kuball, J., Camisa, B., Bondanza, A., Casorati, G., Ponzoni, M., Ciceri, F., Bordignon, C., Greenberg, P. D. Holmes, M. C., Gregory, P. D., Naldini, L., and Bonini, C. (2012). Editing $\mathrm{T}$ cell specificity towards leukemia by zinc finger nucleases and lentiviral gene transfer. Nat. Med. 18, 807-815.

Pule, M. A., Savoldo, B., Myers, G. D., Rossig, C., Russell, H. V., Dotti, G., Huls, M. H., Liu, E., Gee, A. P., Mei, Z., Yvon, E., Weiss, H. L., Liu, H., Rooney, C. M., Heslop, H. E., and Brenner, M. K. (2008). Virus-specific $\mathrm{T}$ cells engineered to coexpress tumor-specific receptors: persistence and antitumor activity in individuals with neuroblastoma. Nat. Med. 14, 1264-1270.

Pulido, J., Kottke, T., Thompson, J., Galivo, F., Wongthida, P., Diaz, R. M., Rommelfanger, D., Ilett, E., Pease, L., Pandha, H., Harrington, K., Selby, P., Melcher, A., and Vile, R. (2012). Using virally expressed melanoma cDNA libraries to identify tumor-associated antigens that cure melanoma. Nat. Biotechnol. 30, 337-344.

Recchia, A., Bonini, C., Magnani, Z., Urbinati, F., Sartori, D., Muraro, S., Tagliafico, E., Bondanza, A., Stanghellini, M. T., Bernardi, M., Pescarollo, A., Ciceri, F., Bordignon, C., and Mavilio, F. (2006). Retroviral vector integration deregulates gene expression but has no consequence on the biology and function of transplanted T cells. Proc. Natl. Acad. Sci. U.S.A. 103, 1457-1462.

Restifo, N. P., Dudley, M. E., and Rosenberg, S. A. (2012). Adoptive immunotherapy for cancer: harnessing the $\mathrm{T}$ cell response. Nat. Rev. Immunol. 12, 269-281.
Robbins, P. F., Dudley, M. E., Wunderlich, J., El Gamil, M., Li, Y. F., Zhou, J., Huang, J., Powell, D. J. Jr., and Rosenberg, S. A. (2004). Cutting edge: persistence of transferred lymphocyte clonotypes correlates with cancer regression in patients receiving cell transfer therapy. J. Immunol. 173, 7125-7130.

Robbins, P. F., Li, Y. F., El Gamil, M., Zhao, Y., Wargo, J. A., Zheng, Z., Xu, H., Morgan, R. A., Feldman, S. A., Johnson, L. A., Bennett, A. D., Dunn, S. M., Mahon, T. M., Jakobsen, B. K., and Rosenberg, S. A. (2008). Single and dual amino acid substitutions in TCR CDRs can enhance antigenspecific T cell functions. J. Immunol. 180, 6116-6131.

Robbins, P. F., Morgan, R. A., Feldman, S. A., Yang, J. C., Sherry, R. M., Dudley, M. E., Wunderlich, J. R., Nahvi, A. V., Helman, L. J., Mackall C. L., Kammula, U. S., Hughes, M. S., Restifo, N. P., Raffeld, M., Lee, C. C., Levy, C. L., Li, Y. F., El Gamil, M., Schwarz, S. L., Laurencot, C., and Rosenberg, S. A. (2011). Tumor regression in patients with metastatic synovial cell sarcoma and melanoma using genetically engineered lymphocytes reactive with NY-ESO-1. J. Clin. Oncol. 29, 917-924.

Rosenberg, S. A., Packard, B. S., Aebersold, P. M., Solomon, D., Topalian, S. L., Toy, S. T., Simon, P., Lotze, M. T., Yang, J. C., Seipp, C. A., Einhorn, J. H., and White, D. E. (1988). Use of tumor-infiltrating lymphocytes and interleukin-2 in the immunotherapy of patients with metastatic melanoma. A preliminary report. N. Engl. J. Med. 319, 16761680.

Rosenberg, S. A., Yang, J. C., Sherry, R. M., Kammula, U. S., Hughes, M. S., Phan, G. Q., Citrin, D. E., Restifo, N. P., Robbins, P. F., Wunderlich, J. R., Morton, K. E., Laurencot, C. M., Steinberg, S. M., White, D. E., and Dudley, M. E. (2011). Durable complete responses in heavily pretreated patients with metastatic melanoma using T-cell transfer immunotherapy. Clin. Cancer Res. 17, 4550-4557.

Rossig, C., Bollard, C. M., Nuchtern, J. G., Rooney, C. M., and Brenner, M. K. (2002). Epstein-Barr virus-specific human $\mathrm{T}$ lymphocytes expressing antitumor chimeric T-cell receptors: potential for improved immunotherapy. Blood 99, 2009-2016.

Sadovnikova, E., and Stauss, H. J. (1996). Peptide-specific cytotoxic $\mathrm{T}$ lymphocytes restricted by nonself major histocompatibility complex class I molecules: reagents for tumor immunotherapy. Proc. Natl. Acad. Sci. U.S.A. 93, 13114-13118.

Saito, T., Hochstenbach, F., MarusicGalesic, S., Kruisbeek, A. M., Brenner, M., and Germain, R. N. (1988) Surface expression of only gamma delta and/or alpha beta $\mathrm{T}$ cell receptor heterodimers by cells with four (alpha, beta, gamma, delta) functional receptor chains. J. Exp. Med. $168,1003-1020$

Savage, P., Gao, L., Vento, K., Cowburn, P., Man, S., Steven, N., Ogg, G., McMichael, A., Epenetos, A., Goulmy, E., and Stauss, H. J. (2004). Use of B cell-bound HLA-A2 class I monomers to generate high-avidity, allo-restricted CTLs against the leukemia-associated protein Wilms tumor antigen. Blood 103, 4613-4615.

Schaft, N., Dorrie, J., Muller, I., Beck, V., Baumann, S., Schunder, T., Kampgen, E., and Schuler, G. (2006a). A new way to generate cytolytic tumor-specific T cells: electroporation of RNA coding for a $\mathrm{T}$ cell receptor into $\mathrm{T}$ lymphocytes. Cancer Immunol. Immunother. 55, 1132-1141.

Schaft, N., Lankiewicz, B., Drexhage, J., Berrevoets, C., Moss, D. J., Levitsky, V., Bonneville, M., Lee, S. P., McMichael, A. J., Gratama, J. W., Bolhuis, R. L., Willemsen, R., and Debets, R. (2006b). T cell retargeting to EBV antigens following TCR gene transfer: CD28-containing receptors mediate enhanced antigenspecific IFNgamma production. Int. Immunol. 18, 591-601.

Schmitt, T. M., Ragnarsson, G. B., and Greenberg, P. D. (2009). T cell receptor gene therapy for cancer. Hum. Gene Ther. 20, 1240-1248.

Schodin, B. A., Tsomides, T. J., and Kranz, D. M. (1996). Correlation between the number of $\mathrm{T}$ cell receptors required for $\mathrm{T}$ cell activation and TCR-ligand affinity. Immunity 5 , 137-146.

Scholten, K. B., Kramer, D., Kueter, E. W., Graf, M., Schoedl, T., Meijer, C. J., Schreurs, M. W., and Hooijberg, E. (2006). Codon modification of $\mathrm{T}$ cell receptors allows enhanced functional expression in transgenic human T cells. Clin. Immunol. 119, 135-145.

Scholten, K. B., Schreurs, M. W. Ruizendaal, J. J., Kueter, E. W. Kramer, D., Veenbergen, S., Meijer, C. J., and Hooijberg, E. (2005). Preservation and redirection of HPV16E7-specific $T$ cell receptors for immunotherapy of cervical cancer. Clin. Immunol. 114, 119-129.
Scholten, K. B., Turksma, A. W., Ruizendaal, J. J., van den, H. M., van der Burg, S. H., Heemskerk, M. H., Meijer, C. J., and Hooijberg, E. (2011). Generating HPV specific $\mathrm{T}$ helper cells for the treatment of HPV induced malignancies using TCR gene transfer. J. Transl. Med. 9, 147.

Schub, A., Schuster, I. G., Hammerschmidt, W., and Moosmann, A. (2009). CMV-specific TCRtransgenic $\mathrm{T}$ cells for immunotherapy. J. Immunol. 183, 6819-6830.

Sebestyen, Z., Schooten, E., Sals, T., Zaldivar, I., San Jose, E., Alarcon, B., Bobisse, S., Rosato, A., Szollosi, J., Gratama, J. W., Willemsen, R. A., and Debets, R. (2008). Human TCR that incorporate CD3zeta induce highly preferred pairing between TCRalpha and beta chains following gene transfer. J. Immunol. 180, 7736-7746.

Sheridan, C. (2011). Gene therapy finds its niche. Nat. Biotechnol. 29, 121-128.

Sherman, L. A., Hesse, S. V., Irwin, M. J., La Face, D., and Peterson, P. (1992). Selecting $\mathrm{T}$ cell receptors with high affinity for self-MHC by decreasing the contribution of CD8. Science 258, 815-818.

Soetandyo, N., Wang, Q., Ye, Y., and Li, L. (2010). Role of intramembrane charged residues in the quality control of unassembled T-cell receptor alpha-chains at the endoplasmic reticulum. J. Cell Sci. 123, 1031-1038.

Sommermeyer, D., Neudorfer, J., Weinhold, M., Leisegang, M., Engels, B., Noessner, E., Heemskerk, M. H., Charo, J., Schendel, D. J., Blankenstein, T., Bernhard, H., and Uckert, W. (2006). Designer T cells by T cell receptor replacement. Eur. J. Immunol. 36, 3052-3059.

Sommermeyer, D. and Uckert, W. (2010). Minimal amino acid exchange in human TCR constant regions fosters improved function of TCR gene-modified $\mathrm{T}$ cells. J. Immunol. 184, 6223-6231.

Stanislawski, T., Voss, R. H., Lotz, C., Sadovnikova, E., Willemsen, R. A., Kuball, J., Ruppert, T., Bolhuis, R. L., Melief, C. J., Huber, C., Stauss, H. J., and Theobald, M. (2001). Circumventing tolerance to a human MDM2-derived tumor antigen by TCR gene transfer. Nat. Immunol. 2, 962-970.

Straathof, K. C., Pule, M. A., Yotnda, P., Dotti, G., Vanin, E. F., Brenner, M. K., Heslop, H. E., Spencer, D. M., and Rooney, C. M. (2005). An inducible caspase 9 safety switch for T-cell therapy. Blood 105, 4247-4254. 
Straetemans, T., van Brakel, M., van Steenbergen, S., Broertjes, M., Drexhage, J., Hegmans, J., Lambrecht, B. N., Lamers, C., Bruggen, P. D., Coulie, P. G., and Debets, R. (2012). TCR gene transfer: MAGE-C2/HLAA2 and MAGE-A3/HLA-DP4 epitopes as melanoma-specific immune targets. Clin. Dev. Immunol. 2012, 586314.

Szymczak, A. L., and Vignali, D. A. (2005). Development of 2A peptidebased strategies in the design of multicistronic vectors. Expert. Opin. Biol. Ther. 5, 627-638.

Theobald, M., Biggs, J., Dittmer, D., Levine, A. J., and Sherman, L .A. (1995). Targeting p53 as a general tumor antigen. Proc. Natl. Acad. Sci. U.S.A. 92, 11993-11997.

Thomas, S., Stauss, H. J., and Morris, E. C. (2010). Molecular immunology lessons from therapeutic T-cell receptor gene transfer. Immunology 129, 170-177.

Thomas, S., Xue, S. A., Bangham, C. R., Jakobsen, B. K., Morris, E. C., and Stauss, H. J. (2011). Human $\mathrm{T}$ cells expressing affinity-matured TCR display accelerated responses but fail to recognize low density of MHC-peptide antigen. Blood 118, 319-329.

Thomas, S., Xue, S. A., Cesco-Gaspere, M., San Jose, E., Hart, D. P., Wong, V., Debets, R., Alarcon, B., Morris, E., and Stauss, H. J. (2007). Targeting the Wilms tumor antigen 1 by TCR gene transfer: TCR variants improve tetramer binding but not the function of gene modified human $\mathrm{T}$ cells. J. Immunol. 179, 5803-5810.

Till, B. G., Jensen, M. C., Wang, J., Chen, E. Y., Wood, B. L., Greisman, H. A., Qian, X., James, S. E., Raubitschek, A., Forman, S. J., Gopal, A. K., Pagel, J. M., Lindgren, C. G., Greenberg, P. D., Riddell, S. R., and Press, O. W. (2008). Adoptive immunotherapy for indolent nonHodgkin lymphoma and mantle cell lymphoma using genetically modified autologous CD20-specific T cells. Blood 112, 2261-2271.

Tsuji, T., Yasukawa, M., Matsuzaki, J., Ohkuri, T., Chamoto, K., Wakita, D., Azuma, T., Niiya, H., Miyoshi, H., Kuzushima, K., Oka, Y., Sugiyama, H., Ikeda, H., and Nishimura, T. (2005). Generation of tumor-specific, HLA class I-restricted human Th1 and Tcl cells by cell engineering with tumor peptide-specific $\mathrm{T}$-cell receptor genes. Blood 106, 470-476.

Uckert, W., and Schumacher, T. N. (2009). TCR transgenes and transgene cassettes for TCR gene therapy: status in 2008. Cancer Immunol. Immunother. 58 809-822.

Udyavar, A., Alli, R., Nguyen, P., Baker, L., and Geiger, T. L. (2009). Subtle affinity-enhancing mutations in a myelin oligodendrocyte glycoprotein-specific TCR alter specificity and generate new self-reactivity. J. Immunol. 182, 4439-4447.

Udyavar, A., and Geiger, T. L. (2010). Rebalancing immune specificity and function in cancer by T-cell receptor gene therapy. Arch. Immunol. Ther. Exp. (Warsz. ) 58, 335-346.

Ueno, T., Tomiyama, H., Fujiwara, M., Oka, S., and Takiguchi, M. (2004). Functionally impaired HIV-specific CD8 $\mathrm{T}$ cells show high affinity TCRligand interactions. J. Immunol. 173, 5451-5457.

van der Veken, L. T., Coccoris, M., Swart, E., Falkenburg, J. H., Schumacher, T. N., and Heemskerk, M. H. (2009). Alpha beta $\mathrm{T}$ cell receptor transfer to gamma delta $\mathrm{T}$ cells generates functional effector cells without mixed TCR dimers in vivo. J. Immunol. 182 164-170.

van der Veken, L. T., Hagedoorn, R. S., van Loenen, M. M., Willemze, R. Falkenburg, J. H., and Heemskerk, M. H. (2006). Alphabeta T-cell receptor engineered gammadelta $\mathrm{T}$ cells mediate effective antileukemic reactivity. Cancer Res. 66, 3331-3337.

van Lent, A. U., Nagasawa, M., van Loenen, M. M., Schotte, R., Schumacher T. N., Heemskerk, M. H., Spits, H., and Legrand, N. (2007). Functional human antigen-specific $\mathrm{T}$ cells produced in vitro using retroviral $\mathrm{T}$ cell receptor transfer into hematopoietic progenitors. J. Immunol. 179 4959-4968.

van Loenen, M. M., de Boer, R., Amir, A. L., Hagedoorn, R. S., Volbeda, G. L., Willemze, R., van Rood, J. J., Falkenburg, J. H., and Heemskerk, M. H. (2010). Mixed T cell receptor dimers harbor potentially harmful neoreactivity. Proc. Natl. Acad. Sci. U.S.A. 107, 10972-10977.

van Loenen, M. M., Hagedoorn, R. S., de Boer, R., van Egmond, E. H., Falkenburg, J. H., and Heemskerk, M. H. (2011). Rapid reexpression of retrovirally introduced versus endogenous TCRs in engineered $\mathrm{T}$ cells after antigen-specific stimulation. J. Immunother. 34, 165-174.

Varela-Rohena, A., Molloy, P. E., Dunn, S. M., Li, Y., Suhoski, M. M., Carroll, R. G., Milicic, A., Mahon, T.,
Sutton, D. H., Laugel, B., Moysey, R. Cameron, B. J., Vuidepot, A., Purbhoo, M. A., Cole, D. K., Phillips, R. E., June, C. H., Jakobsen, B. K. Sewell, A. K., and Riley, J. L. (2008). Control of HIV-1 immune escape by CD8 $\mathrm{T}$ cells expressing enhanced T-cell receptor. Nat. Med. 14 1390-1395.

Voss, R. H., Kuball, J., Engel, R., Guillaume, P., Romero, P., Huber, C., and Theobald, M. (2006). Redirection of $\mathrm{T}$ cells by delivering a transgenic mouse-derived MDM2 tumor antigen-specific TCR and its humanized derivative is governed by the CD8 coreceptor and affects natural human TCR expression. Immunol. Res. 34, 67-87.

Voss, R. H., Thomas, S., Pfirschke, C., Hauptrock, B., Klobuch, S., Kuball, J. Grabowski, M., Engel, R., Guillaume, P., Romero, P., Huber, C., Beckhove, P., and Theobald, M. (2010). Coexpression of the T-cell receptor constant alpha domain triggers tumor reactivity of single-chain TCRtransduced human T cells. Blood 115 , 5154-5163.

Voss, R. H., Willemsen, R. A., Kuball, J., Grabowski, M., Engel, R., Intan, R. S., Guillaume, P., Romero, P., Huber, C., and Theobald, M. (2008). Molecular design of the Calphabeta interface favors specific pairing of introduced TCRalphabeta in human $\mathrm{T}$ cells. J. Immunol. 180, 391-401.

Vyas, J. M., van der Veen, A. G., and Ploegh, H. L. (2008). The known unknowns of antigen processing and presentation. Nat. Rev. Immunol. 8, 607-618.

Walchli, S., Loset, G. A., Kumari, S., Johansen, J. N., Yang, W., Sandlie, I., and Olweus, J. (2011). A practical approach to T-cell receptor cloning and expression. PLoS ONE 6, e27930. doi: 10.1371/journal.pone. 0027930

Walter, E. A., Greenberg, P. D., Gilbert, M. J., Finch, R. J., Watanabe, K. S., Thomas, E. D., and Riddell, S. R. (1995). Reconstitution of cellular immunity against cytomegalovirus in recipients of allogeneic bone marrow by transfer of T-cell clones from the donor. N. Engl. J. Med. 333, 1038-1044.

Wang, X., Berger, C., Wong, C. W. Forman, S. J., Riddell, S. R., and Jensen, M. C. (2011). Engraftment of human central memory-derived effector CD8+ T cells in immunodeficient mice. Blood 117, 1888-1898.

Woodworth, J. S., Wu, Y., and Behar, S. M. (2008). Mycobacterium tuberculosis-specific CD8+ T cells require perforin to kill target cells and provide protection in vivo. J. Immunol. 181, 8595-8603.

Wright, G. P., Notley, C. A., Xue, S. A., Bendle, G. M., Holler, A., Schumacher, T. N., Ehrenstein, M. R., and Stauss, H. J. (2009). Adoptive therapy with redirected primary regulatory $\mathrm{T}$ cells results in antigenspecific suppression of arthritis. Proc. Natl. Acad. Sci. U.S.A. 106, 1907819083.

Yang, L., and Baltimore, D. (2005). Long-term in vivo provision of antigen-specific $\mathrm{T}$ cell immunity by programming hematopoietic stem cells. Proc. Natl. Acad. Sci. U.S.A. 102, 4518-4523.

Yang, S., Cohen, C. J., Peng, P. D., Zhao, Y., Cassard, L., Yu, Z., Zheng, Z., Jones, S., Restifo, N. P., Rosenberg, S. A., and Morgan, R. A. (2008). Development of optimal bicistronic lentiviral vectors facilitates high-level TCR gene expression and robust tumor cell recognition. Gene Ther. 15, 1411-1423.

Yang, S., Luca, G., Liu, F., Ji, Y., Yu, Z., Restifo, N. P., Rosenberg, S. A., and Morgan, R. A. (2011). In vitro generated anti-tumor $\mathrm{T}$ lymphocytes exhibit distinct subsets mimicking in vivo antigen-experienced cells. Cancer Immunol. Immunother. 60, 739-749.

Zhang, Y., Liu, Y., Moxley, K. M., Golden-Mason, L., Hughes, M. G., Liu, T., Heemskerk, M. H., Rosen, H. R., and Nishimura, M. I. (2010). Transduction of human $\mathrm{T}$ cells with a novel $\mathrm{T}$-cell receptor confers anti-HCV reactivity. PLoS Pathog. 6, e1001018. doi: 10.1371/journal. ppat.1001018

Zhao, Y., Bennett, A. D., Zheng, Z., Wang, Q. J., Robbins, P. F., Yu, L. Y., Li, Y., Molloy, P. E., Dunn, S. M., Jakobsen, B. K., Rosenberg, S. A., and Morgan, R. A. (2007a). Highaffinity TCRs generated by phage display provide CD4+ T cells with the ability to recognize and kill tumor cell lines. J. Immunol. 179, 58455854.

Zhao, Y., Moon, E., Carpenito, C., Paulos, C. M., Liu, X., Brennan, A. L., Chew, A., Carroll, R. G., Scholler, J., Levine, B. L., Albelda, S. M., and June, C. H. (2010). Multiple injections of electroporated autologous $\mathrm{T}$ cells expressing a chimeric antigen receptor mediate regression of human disseminated tumor. Cancer Res. 70, 9053-9061.

Zhao, Y., Parkhurst, M. R., Zheng, Z., Cohen, C. J., Riley, J. P., Gattinoni, L., Restifo, N. P., Rosenberg, S. A., and Morgan, R. A. (2007b). Extrathymic 
generation of tumor-specific $\mathrm{T}$ cells from genetically engineered human hematopoietic stem cells via Notch signaling. Cancer Res. 67, 24252429.

Zhao, Y., Zheng, Z., Cohen, C. J., Gattinoni, L., Palmer, D. C., Restifo, N. P., Rosenberg, S. A., and Morgan, R. A. (2006a). High-efficiency transfection of primary human and mouse $\mathrm{T}$ lymphocytes using RNA electroporation. Mol. Ther. 13, 151-159.
Zhao, Y., Zheng, Z., Khong, H. T., Rosenberg, S. A., and Morgan, R. A. (2006b). Transduction of an HLA-DP4-restricted NY-ESO-1specific TCR into primary human CD4+ lymphocytes. J. Immunother. 29, 398-406.

Conflict of Interest Statement: The authors declare that the research was conducted in the absence of any commercial or financial relationships that could be construed as a potential conflict of interest.

Received: 12 April 2012; paper pending published: 07 May 2012; accepted: 15 June 2012; published online: 06 July 2012. Citation: Daniel-Meshulam I, Ya'akobi S, Ankri C and Cohen CJ (2012) How (specific) would you like your T-cells today? Generating T-cell therapeutic function through TCR-gene transfer. Front. Immun. 3:186. doi: 10.3389/fimmu. 2012.00186
This article was submitted to Frontiers in Tumor Immunity, a specialty of Frontiers in Immunology.

Copyright (c) 2012 Daniel-Meshulam, Ya'akobi, Ankri and Cohen. This is an open-access article distributed under the terms of the Creative Commons Attribution License, which permits use, distribution and reproduction in other forums, provided the original authors and source are credited and subject to any copyright notices concerning any thirdparty graphics etc. 